\title{
I-14 高速道路転換率モデルを組み込んだ確率的均衡配分の実用化 \\ Stochastic User Equilibrium Assignment Adopting Expressway Diversion Function
}

\author{
雲林院康宏 ${ }^{1}$ \\ Yasuhiro Ujii ${ }^{1}$
}

藤田 素弘 ${ }^{2}$

松井 寛 ${ }^{3}$

Motohiro Fujita ${ }^{2}$

Hiroshi Matsui ${ }^{3}$

【抄録】高速道路を含む大都市圈道路ネットワークを対象とする交通量配分において, 本研究では,実務 的によく使われている高速道路転換率モデルを,論理的に利点の多い確率的均衡配分モデルへ組み込ん だ,害用的なモデルを開発した.さらに,開発したモデルを名古屋圈の実規模ネットワークへ適用し,その 実績再現性を検証することによって,高速道路，一般道ともに比較的高い精度で推定できることがわかり， これらの経路選択における分散特性も明らかにすることができた.

【Abstract】 To estimate traffic assignment for urban road network including expressways, we propose a utility model which the stochastic user equilibrium assignment model adopts a diversion function that determines the ratio of traffic demand passing expressways between each OD pair(expressway diversion function). Furthermore, this model is applied to a real-scale road network in Nagoya metropolitan city, the results show good accuracy and it is clear that the diversity of path choice on highway and freeway network.

\section{【キーワード】交通量推計,高速道路,高速道路転換率,確率的均衡配分}

【Keywords】 traffic flow estimation, expressway, expressway diversion function, stochastic user equilibrium assignment

1.はじめに

交通量配分は,標準的な交通需要予測手法であ る 4 段階推定法（交通の発生·集中一分布一分担 一配分）の第 4 段階に位置づけられており,道路 ネットワーク上において,それぞれ固有の出発地 と目的地を持ったドライバーの経路選択を予測
し,その経路交通量及びネットワークを構成する リンクの交通量の推計を目的としている.今日ま でに多くの実用的な交通量配分モデルが提案さ れているが,その中でも近年,利用者均衡配分モデ ルが注目されており,その発展型モデルとして知 られている確率的均衡配分モデル ${ }^{1)}$ は,不完全情 報下における経路選択のランダム性を考慮でき

1: 名古屋工業大学大学院工学研究科博士後期課程都市循環システム工学専攻

(TEL052-732-2111,E-mail:ujii@keik1.ace.nitech.ac.jp)

2: 名古屋工業大学大学院ながれ領域(TEL052-732-2111,E-mail:fujita@doboku2.ace.nitech.ac.jp)

$3:$ 名城大学理工学部建設システム工学科(TEL052-832-1151,E-mail: hmatsui@ccmfs.meijo-u.ac.jp) 
ること及び実務においてニーズの高い経路交通 量が一意的に定まることが利点である.

表一 1 各都市高速道路の転換率モデル

\begin{tabular}{|c|c|c|c|}
\hline 首都高速道路公団 & $\begin{array}{l}\text { 名古屋高速 } \\
\text { 道路公社 }\end{array}$ & $\begin{array}{l}\text { 阪神高速 } \\
\text { 道路公団 }\end{array}$ & $\begin{array}{c}\text { 福岡北九州高速 } \\
\text { 道路公社 }\end{array}$ \\
\hline$p=\left(\frac{1}{1+T^{6}}-0.05\right) \alpha$ & $p=\frac{1}{1+T^{6}}-0.05$ & $p=\frac{1}{1+\alpha T^{3}}-0.03$ & $\mathrm{p}=\left(\frac{1}{1+\mathrm{T}^{6}}-0.005\right) \alpha$ \\
\hline $\begin{array}{l}\text { :走行時間比 } \\
\alpha: \text { :短卜リップ低減係数 } \\
(\alpha=0.047 D+0.2696) \\
D: \text { 高速本線走行距離 }\end{array}$ & $\mathrm{T}$ :競合時間比 & $\begin{array}{l}\mathrm{T}: \text { 競合時間比 } \\
\alpha: \text { パラメータ } \\
(\alpha=3)\end{array}$ & $\begin{array}{l}\mathrm{T}: \text { 走行時間比 } \\
\alpha \text { :短トリップ低減係 } \\
\text { 数 } \\
(\alpha=(L-1) / 4) \\
\mathrm{L}: \text { 本線利用距離 } \\
(\mathrm{L}<5 \mathrm{~km})\end{array}$ \\
\hline
\end{tabular}

注)走行時間比は高速利用経路走行時間に対する一般道利用経路走行時間の比

競合時間比は高速道路部走行時間に対する一般道利用経路走行時間の比

一方, 大都市圈内の広域道路網の中には, 通常, 有料制をとる高速道路が含まれている. 利用者均 衡配分理論では高速道路の所要時間を,料金を含 む一般化所要時間で扱うことはできるが, 高速道 路を利用するか, 又は, 一般道のみを利用するか についての転換行動では個人属性等による分散 要因がより大きくなり,一般化所要時間だけでは 十分に表現できないと言える。これを考慮可能な 交通量配分モデルとして, 高速道路転換率モデル を分割配分法（均衡配分法の近似的解法）に組み 込む配分モデル（高速道路転換率併用型分割配分 モデル）がこれまで実務においてよく利用されて きた.なお, 表一 1 は各都市高速道路の高速道路 転換率モデルを示している. しかし, 前述の利点 を有する確率的均衡配分に高速道路転換率モデ ルを組み込んだ配分モデルはまだ開発されてい ない.

以上のような背景から本研究では, 高速道路転 換率モデルを確率的均衡配分に組み込んだ,実用 的なモデルを開発する.さらに,開発したモデルを 名古屋圏の実規模ネットワークへ適用し,その実 績再現性を検証する.本研究で適用するネットワ 一クはノード数 1241（そのうち, セントロイド数 279）, 往復別リンク数 4209 で構成される大規模 ネットワークである.そのため, Simplicial Decomposition 法（4 章参照）を応用した確率的 均衡配分の実用化は今までに研究事例がなく,そ の実現は,すべての0Dペアの経路交通量を記憶す る膨大なメモリー, 収束計算を行うための高性能 な CPU等のコンピュータの大幅な性能向上に起因 するところが大きい.

ところで,著者ら ${ }^{233)}$ は, 数理計画問題として取
り扱いができ,操作性が高い,期待最小コストを変 数とする高速道路転換率モデル（次式）を組み込 んだ確率的均衡配分モデルの構築を試みている が,その実用化には至っていない。

$$
\begin{array}{r}
g_{r s}^{e}=G_{r s} \frac{1}{\exp \left\{-\theta_{r s}\left(S_{r s}-S_{r s}^{e}\right)+\psi_{r s}\right\}+1} \\
\text { ただし, } \quad S_{r s}=-\frac{1}{\mu} \ln \sum_{k} \exp \left[-\mu C_{k}^{r s}\right] \\
S_{r s}^{e}=-\frac{1}{\mu^{e}} \ln \sum_{k} \exp \left[-\mu^{e} C_{k}^{r s, e}\right]
\end{array}
$$

$g_{r s}^{e}: \mathrm{OD} ヘ ゚ ア r s$ 間の高速道路利用の $\mathrm{OD}$ 交通量 $G_{r s}: \mathrm{OD} ヘ ゚ ア \mathrm{rs}$ 間の全 $\mathrm{OD}$ 交通量

$C_{k}^{r s} ： \mathrm{rs}$ 間経路 $\mathrm{k}$ の一般道利用経路コスト（分） $C_{k}^{r s, e}: \mathrm{rs}$ 間経路 $\mathrm{k}$ の高速道路利用経路コスト(分) （料金コストを含む）

$S_{r s}: \mathrm{rs}$ 間一般道利用経路の期待最小コスト $S_{r s}^{e}: \mathrm{rs}$ 間高速道路利用経路の期待最小コスト

$\mu$ :一般道利用経路の選択のバラツキを表す分散 パラメータ

$\mu^{e}$ : 高速道路利用経路の選択のバラツキを表す 分散パラメータ

$\theta_{r s}, \psi_{r s}:$ 高速道路転換率パラメータ

それは, 実ネットワークへの適用において, 高 速道路転換率モデルがアンケート結果（ODペア 間平均所要時間データ) から構築されることや, 期待最小コストと平均コストの特性 (3 章, 5 章参 照）を考えると, 現実的な意味を持つ平均コスト を利用することが妥当と考えられたためである. よって本研究では新たに平均コストで定義され る高速道路転換率モデルを組み込んだ需要変動 型確率的均衡配分モデルの開発実用化を行うこ とを目的とする.

現実的に見られる利用者の経路選択の多様性 や情報の不完全性に注目した均衡配分手法 4)5)の 従来なされた研究を概観すると,需要固定型確率 的均衡配分モデルは Daganzo and Sheffi1)や Fisk ${ }^{6)}$ によって定式化された.また,その実用化で は宮城 7)や溝上 8 )の研究がある.一方;需要変動型 確率的均衡配分モデルについては赤松 9)によって モデルの定式化と解法が示された。 
$x_{a}:$ リンク $\mathrm{a}$ のリンク交通量

$\delta_{r s, k, a}:(1:$ リンク a が一般道利用経路 $\mathrm{k}$ に含まれ るとき，0:そうでないとき）

$\delta_{r s, k, a}^{e}:(1:$ リンク a が高速道路利用経路 $\mathrm{k}$ に含ま れるとき，0:そうでないとき)

$g_{r s}^{e}, G_{r s}, C_{k}^{r s}, C_{k}^{r s, e}, \mu, \mu^{e}, \theta_{r s}, \psi_{r s}$ は式(1)の定義 と同様

本研究の問題は,リンクコスト関数が各リンク で分離可能であり,単調増加関数である.このよう な条件をもつ需要変動型確率的均衡配分の場合, ロジット型需要関数が期待最小コストを変数と するものであれば,通常,数理最適化問題として再 定式化できる ${ }^{10)}$.しかし,本研究のロジット型需要 関数には平均コストを利用していることから,数 理最適化問題への再定式化はできない.

このモデルは,Yang11)が交通情報提供下のドラ イバーとそうでないドライバー間の需要変動を 組み込んだ確率的均衡配分モデルと同様の問題 となっている.Yang は平均コストを利用する需要 変動型確率的均衡配分では,解は存在するものの, 唯一性は保証されないことを証明するとともに， そのアルゴリズムを示した.本研究のモデルでも 同等に解の一意性は証明できないが,Yang の方法 とは異なるアルゴリズムを用いて,大規模ネット ワークにおける収束性と配分精度を 5 章におい て実証的に検証するものとする.

ところで,本研究の需要関数(高速道路転換率モ デル）に,期待最小コストではなく,平均コストを 利用する理由は, 高速道路転換率モデルが現実の $\mathrm{OD} ヘ ゚ ア$ 間平均所要時間データから求められて いるためである.期待最小コストと平均コストが ほぼ同一であれば,近似的に期待最小コストを利 用することも可能であるが,一般にそれは分散パ ラメータの值によって異なるといえる.このこと に関して,次章では期待最小コストと平均コスト の特性を比較し,平均コストで定式化する必要性 について考察するものとする。

\section{3. 確率的均衡配分モデルにおける分散パラタメータ}

\section{1 分散パラメータと経路選択確率}

ここでは,表-2 左端の列に示すように 10 本の経 路について, 経路コストが 30 分から 39 分まで既 に与えられている簡単なケースを考える. 経路選 択確率は,式(8),式(9)のようなロジットモデルを 仮定している.

表-2 は分散パラメータ $[10,30,60,100 ， 500]$ $(1 / \mathrm{hr})$ の值に対して各経路選択確率の変化を見 たものである. 分散パラメータが 10 のとき, 経路 選択確率 $5 \%$ 以上である経路の経路コストは最短 経路コスト (30 分) から+7 分までである. しかし, 分散パラメータが大きくなる (経路選択は確定的 になる) と, 経路選択確率 $5 \%$ 以上である経路は, 分散 30 で最短経路コスト+4 分, 分散 60 で+2 分, 分散 100 以上では+1 分以内の経路に絞られて, 分 散が大きくなるほど確定的な配分に近づくこと がわかる. 表-2 の結果は, 経路数と経路コストが 与えられ, フローインディペンデントな条件の下 での結果であり，現実の均衡配分下での状況とは 幾分異なるものの,おおよその傾向は読み取るこ とができる.

表-2 分散パラメー夕と各経路の選択確率の関係

\begin{tabular}{|r|c|c|c|c|c|c|}
\hline \multirow{2}{*}{ No } & 経路コス & \multicolumn{5}{|c|}{ 分散パラメータ } \\
\cline { 3 - 7 } & 10 & 30 & 60 & 100 & 500 \\
\hline 1 & 30 & 0.1893 & 0.3961 & 0.6321 & 0.8111 & 0.9998 \\
\hline 2 & 31 & 0.1602 & 0.2403 & 0.2326 & 0.1532 & 0.0002 \\
\hline 3 & 32 & 0.1356 & 0.1457 & 0.0856 & 0.0289 & 0.0000 \\
\hline 4 & 33 & 0.1148 & 0.0884 & 0.0315 & 0.0055 & 0.0000 \\
\hline 5 & 34 & 0.0972 & 0.0536 & 0.0116 & 0.0010 & 0.0000 \\
\hline 6 & 35 & 0.0823 & 0.0325 & 0.0043 & 0.0002 & 0.0000 \\
\hline 7 & 36 & 0.0696 & 0.0197 & 0.0016 & 0.0000 & 0.0000 \\
\hline 8 & 37 & 0.0589 & 0.0120 & 0.0006 & 0.0000 & 0.0000 \\
\hline 9 & 38 & 0.0499 & 0.0073 & 0.0002 & 0.0000 & 0.0000 \\
\hline 10 & 39 & 0.0422 & 0.0044 & 0.0001 & 0.0000 & 0.0000 \\
\hline
\end{tabular}

\section{2 期待最小コストと平均コスト}

表-3 は,表-2 と同じ経路数と経路コストを持つ ネットワークにおいて, 分散パラメータと期待最 小コスト・平均コストの関係を見たものである. 期待最小コストは,式(2)によって与えられるが,表 -1 においては 1 ODペアの経路 $\mathrm{k} （=1-10 ）$ で適 用している.平均コストは, 表- 2 に示す経路選択 確率と経路コストの積を合計したものである.

表-2 より,分散パラメータが 70 以上のときは, 期待最小コスト,平均コストはともにほぼ最短経 路コスト（30 分）で大きな違いはない。これら 
しかし,これまでの研究例では,平均コストによ る高速道路転換率モデルを組み込んだ確率的均 衡配分モデルを構築し,実規模ネットワークへの 適用計算及び高速道路と一般道の分散特性を明 示的に分析した例はないといえる。

本研究の構成は以下のようになる.2 章では,高 速道路を考慮した確率的均衡配分モデルの前提 条件と定式化をおこなう. 3 章では,期待最小コス 卜,平均コスト及び分散パラメータの関係を考察 し, 本研究の平均コストによる高速道路転換率モ デルの妥当性を検討する．4 章では,Simplicial Decomposition 法を応用したモデルの解法を示 す. 5 章では,本研究で開発したモデルを実ネット ワークに適用して精度検証をおこなうとともに， 高速道路と一般道の経路分散特性について実証 的に分析する。

\section{2. 高速道路転換率を含む確率的均衡配分モデル の定式化}

\section{1 モデルの前提条件}

ここでは,一般道のみの道路網による最短経路 と高速道路を含めた道路網による最短経路をそ れぞれ一般道利用経路と高速道路利用経路と定 義する.

本研究で扱う高速道路転換率を内生化した確 率的均衡配分モデルは,各需要 OD 交通量を高速 道路転換率を用いてあらかじめ高速道路利用と 一般道利用の OD に分割する.このとき一般道利 用 OD の経路選択は料金を含まない経路所要時 間に関する確率的均衡に従い,高速道路利用 $\mathrm{OD}$ の経路選択は料金を含む一般化所要時間に関す る確率的均衡に従う.すなわち, 本モデルでは, 高 速道路への転換行動と一般道利用の経路選択お よび高速道路利用の経路選択がそれぞれ異なる 分散を持って確率的に行われているものとして モデルを構築する.

またこここでの高速道路料金は車種別ではなく 車種別混入率を考慮した平均的な值を使う. 料金 は全てリンクごとに分解して与えるものとする. また,一般道利用交通量と高速道路利用交通量の リンクコスト関数は共通であるとし,単調増加で
各リンクで分離可能な BPR 型関数を利用するも のとする.

高速道路転換率モデルは, 高速道路および一般 道利用経路の平均コストを変数とするロジット 型需要関数によるものとする.

一般道利用経路と高速道路利用経路の経路選 択は,各経路で異なる分散パラメータを持つロジ ット型確率経路選択に従うものとする。

\section{2 モデルの定式化}

前節のような前提条件をもつ高速道路転換率 モデルを考慮した確率的均衡配分モデルは,以下 の均衡条件をすべて満足する状態として定式化 される。

a） 高速道路転換率モデル

$$
\begin{aligned}
& g_{r s}^{e}=G_{r s} \frac{1}{\exp \left\{-\theta_{r s}\left(\bar{C}_{r s}-\bar{C}_{r s}^{e}\right)+\psi_{r s}\right\}+1} \\
& g_{r s}+g_{r s}^{e}=G_{r s} \\
& \bar{C}_{r s}=\sum_{k} \frac{f_{k}^{r s}}{G_{r s}-g_{r s}^{e}} C_{k}^{r s} \\
& \bar{C}_{r s}^{e}=\sum_{k} \frac{f_{k}^{r s, e}}{g_{r s}^{e}} C_{k}^{r s, e}
\end{aligned}
$$

b） 経路選択モデル

$$
\begin{aligned}
& f_{k}^{r s}=\left(G_{r s}-g_{r s}^{e}\right) \frac{\exp \left(-\mu C_{k}^{r s}\right)}{\sum_{k} \exp \left(-\mu C_{k}^{r s}\right)} \\
& f_{k}^{r s, e}=g_{r s}^{e} \frac{\exp \left(-\mu^{e} C_{k}^{r s, e}\right)}{\sum_{k} \exp \left(-\mu^{e} C_{k}^{r s, e}\right)}
\end{aligned}
$$

c）交通フローの保存条件

$$
\begin{gathered}
\sum_{k} f_{k}^{r s}-g_{r s}=0 \\
\sum_{k} f_{k}^{r s, e}-g_{r s}^{e}=0 \\
x_{a}=\sum_{r s} \delta_{r s, k, a} f_{k}^{r s}+\sum_{r s} \delta_{r s, k, a}^{e} f_{k}^{r s, e} \\
f_{k}^{r s} \geq 0 \quad f_{k}^{r s, e} \geq 0 \quad g_{r s} \geq 0 \quad g_{r s}^{e} \geq 0 \quad x_{i j} \geq 0
\end{gathered}
$$

ここで,

$\bar{C}_{r s}: \mathrm{OD} \wedge^{\circ} ア \mathrm{rs}$ 間の一般道利用経路の平均了久卜

$\bar{C}_{r s}^{e}: \mathrm{OD} \wedge^{\circ} \ni \mathrm{rs}$ 間の高速道路利用経路の平均工外 $f_{k}^{r s}: \mathrm{OD} \wedge^{\circ} ア \mathrm{rs}$ 間の一般道利用経路 $\mathrm{k}$ の交通量 $f_{k}^{r s, e}: \mathrm{OD} \wedge^{\circ} ア \mathrm{rs}$ 間の高速道路利用経路 $\mathrm{k}$ の交通 量 $g_{r s}: \mathrm{OD} ヘ ゚ ア r s$ 間の一般道利用の OD 交通量 
の差は,分散パラメータが小さくなるにつれて大 きくなる.分散パラメータが小さくなると,交通量 が最短経路以外の経路に多く流れるようになる ため,平均コストは最短経路コストよりも徐々に 大きくなる. 一方, 期待最小コストは分散 20 以下 から最短経路コストよりも大きく下回る值を示 している.この結果から期待最小コストが選択可 能な経路のどの経路よりも小さな值を示す特徴 をもち,分散パラメータが小さくなるほどその傾 向が強くなるという基本的特性を確認すること ができる.

表-3 分散パラメータと期待最小コスト・平均コスト

\begin{tabular}{|r|r|r|r|}
\hline $\begin{array}{r}\text { 分散パラ } \\
x \text { 外 } 1 \text { hr) }\end{array}$ & $\begin{array}{r}\text { 期待最小 } \\
\text { コスト (A) }\end{array}$ & $\begin{array}{r}\text { 平均コ } \\
\text { スト }(\mathrm{B})\end{array}$ & $\begin{array}{c}\text { コスト差 } \\
(\mathrm{A}-\mathrm{B})\end{array}$ \\
\hline 1 & -103.72 & 34.36 & -138.08 \\
\hline 5 & 6.53 & 33.82 & -27.29 \\
\hline 10 & 20.01 & 33.19 & -13.18 \\
\hline 20 & 26.33 & 32.16 & -5.83 \\
\hline 30 & 28.15 & 31.47 & -3.32 \\
\hline 40 & 28.92 & 31.04 & -2.12 \\
\hline 50 & 29.32 & 30.77 & -1.45 \\
\hline 60 & 29.54 & 30.58 & -1.04 \\
\hline 70 & 29.68 & 30.45 & -0.77 \\
\hline 80 & 29.77 & 30.36 & -0.59 \\
\hline 90 & 29.83 & 30.29 & -0.46 \\
\hline 100 & 29.87 & 30.23 & -0.36 \\
\hline \multicolumn{3}{|c}{} \\
\hline
\end{tabular}

\section{4. モデルの解法}

高速道路転換率を内生化した確率的均衡配分 モデル $\{$ 式(4)〜式(13) $\}$ は, 高速道路転換率モデル に平均コストを用いており,数理最適化問題とし ては定式化できないため,一般的な数値計算手法 は利用できない.しかしながら,本研究では,需要 関数に期待最小コストを用いて得られる,需要変 動型確率的均衡モデルの数理最適化問題を利用 する解法を考える.すなわち本研究では以下の数 理最適化問題を補助問題として解法に利用する.

【補助問題】

$$
\begin{aligned}
& \min . Z=\sum_{a} \int_{0}^{x_{a}} t_{a}(y) d y \\
& +\sum_{r s} \int_{0}^{g_{r s}^{e}}\left(\frac{1}{\theta_{r s}} \ln \frac{w}{G_{r s}-w}+\psi_{r s}+\theta_{r s} \xi_{r s}\right) d w \\
& -\frac{1}{\mu} \sum_{r s} g_{r s} H_{r s}-\frac{1}{\mu^{e}} \sum_{r s} g_{r s}^{e} H_{r s}^{e}
\end{aligned}
$$

$$
\text { ただし } \begin{aligned}
H_{r s} & =-\sum_{k} \frac{f_{k}^{r s}}{g_{r s}} \ln \frac{f_{k}^{r s}}{g_{r s}} \\
H_{r s}^{e} & =-\sum_{k} \frac{f_{k}^{r s, e}}{g_{r s}^{e}} \ln \frac{f_{k}^{r s, e}}{g_{r s}^{e}}
\end{aligned}
$$

制約条件 : 交通フローの保存条件 \{式 (5), (10) (13)\}

ここで,

$t_{a}(\bullet):$ リク a のリンクコスト関数

$\xi_{r s}$ : 補正パラメータ（補助問題において定数）

補助問題の解の一意性については,一般的な需 要変動型確率的均衡問題と同等であることから 保障される ${ }^{10)}$. 補助問題の最適性条件は,制約条件 を取り込んだ Lagrange 関数を定義することによ り導出できる.まず,Lagrange 関数の $f_{k}^{r s}, f_{k}^{r s, e} に$ 関する Kuhn-Tucker 条件より,経路選択に関する 式(8),式(9)のような最適性条件が得られる. 次に Lagrange 関数の $g_{r s}, g_{r s}^{e}$ に関する Kuhn-Tucker 条 件より, 次式のような最適性条件が得られる。

$$
g_{r s}^{e}=G_{r s} \frac{1}{\exp \left\{\theta_{r s}\left(S_{r s}-S_{r s}^{e}-\xi_{r s}\right)+\psi_{r s}\right\}+1}
$$

この補助問題を解く場合において変数 $\xi_{r s}$ は定 数である.補助問題の均衡解が元問題 $\{$ 式(4)〜式 (13)\}の解であるためには,予め定数として与えら れる $\xi_{r s}$ が,均衡配分後に求められる期待最小コス トと平均コストの次式の関係式を結果的に満た していればよい.

$\xi_{r s}=\left(S_{r s}-S_{r s}^{e}\right)-\left(\overline{C_{r s}}-\overline{C_{r s}^{e}}\right)$

このとき,補助問題の最適解は平均コ人トをも つ高速道路転換率モデルの式(4) と同等の解をあ たえることになる.上式を満たす $\xi_{r s}$ を最初から 与えるのは不可能であるので,以下の計算手順で, 式(16)を満たす $\xi_{r s}$ が最適化問題の結果として得 られる解を探索する。

【元問題 \{式(4)〜式(13)\}】の計算アルゴリズム Step0 初期值, $\xi_{r s}^{(1)}, \mathrm{n}=1$ を設定する.

Step 1 数理最適化問題【補助問題】(付録参照) を解き,各コストを求める.

Step2 次式により更新する. 
$\xi_{r s}^{(n+1)}=\left(S_{r s}^{(n)}-S_{r s}^{e(n)}\right)-\left(\overline{C_{r s}^{(n)}}-\overline{C_{r s}^{e(n)}}\right)$

Step3 あらかじめ設定した $\varepsilon に$ 対して $\max ^{r s}\left|\left(\xi_{r s}^{(n+1)}-\xi_{r s}^{(n)}\right) / \xi_{r s}^{(n)}\right| \leq \varepsilon$

を満足するならば,計算を終了する.そうでなけれ ば,n=n+1 とおいて Step1へ戻る

ところで,Yang ${ }^{11)}$ は平均コストで定式化した需 要変動型確率的均衡問題について,本研究とは別 の補助問題である固定需要型確率的均衡問題を 解く方法を提案しているが,必ずしも解が収束す ることは保障されないとしている.本研究では需 要変動型確率的均衡で数理最適化問題として定 式化される補助問題をアルゴリズムに利用した が,この解の安定性,収束性の保証はされないため, 次章で実証的に検証するものとする.

\section{5. 実ネットワークへの適用}

\section{1 各パラメータの設定}

リンクコスト関数は式(17)を用いる. 料金を含 まない一般道リンクでは式(17)右辺第 2 項の料金 項は除かれる.

$t_{a}=t_{a 0}\left\{1+\alpha\left(\frac{x_{a}}{C_{a}}\right)^{\beta}\right\}+t c_{a} / \gamma$

ここに,

$t_{a}:$ リンク $a$ の単位距離あたり所要時間

$t_{a 0}$ : リンク $a$ の単位距離あたりの自由走行時間

$x_{a}$ : リンク $a$ のリンク交通量

$C_{a}$ : リンク $a$ の日交通容量

$\gamma:$ 時間価值

$t c_{a}:$ :リンク $a$ の通行料金

$\alpha, \beta:$ パラメータ

$t_{a 0}$ と $\alpha, \beta$ のパラメータ,時間価值（65 円/分） および, 高速道路料金の各個別リンクへの推計モ デルは文献 12)で利用したものと同様である.高速 道路転換率モデル $\{$ 式(4)\} のパラメー夕は,従来 研究 12）の日単位の高速道路転換率モデルで設定 された次式を用いる.
$\theta\left(L_{r s}\right)=2.2008 L_{r s}^{-0.9635}$

$\psi\left(L_{r s}\right)=0.4415 \ln \left(L_{r s}\right)+0.5524$

$L_{r s}: \mathrm{OD}$ ペア $\mathrm{rs}$ 間の距離 $(\mathrm{km})$

これらは, 第 7 回名古屋高速道路自動車起終点 調査 ${ }^{13)}$ のデー夕(高速道路利用平均所要時間と交 通量) と PT 調査データ ${ }^{14)}$ (一般道利用平均所要時 間と交通量)を用いて設定されたものである。配 分計算に用いる $0 \mathrm{D}$ 交通量は「平成 3 年度中京都 市圈パーソントリップ調査」 ${ }^{14)}$ を一部補正して, 各種実測データ（高速道路利用台数や転換率用デ 一夕）の平成 8 年用に推計したもの ${ }^{15)}$ を用いる. モデルの適合度比較にもちいる実績交通量は平 成 6 年道路交通センサス ${ }^{16)}$ より得た一般道交通 量（128 個）と車両感知器データとして入手した 高速道路交通量（41 個）である.

\section{2 配分結果と考察}

ここでは本研究で開発した,平均コストによる 高速道路転換率内生型確率的均衡モデルの精度 検証をおこなう。

\section{1 ）モデルの収束状況}

本研究で開発した計算アルゴリズムの収束状 況を検証する.まず図-1は，亦を固定した後の補助 問題の目的関数について Simplecial Deconposition 法による収束状況例（ $\xi=6$ 分） を示しており,この目的関数は経路生成回数 18 回 で滑らかに収束している.

図-2 は,元問題の収束状況を示しており,すべて の $\mathrm{OD}$ ペアの $\xi$ の平均值を $\xi$ の更新回数との関 係で示している.初期值による収束状況の変化も みるために,ここでは $\xi を$ 各 OD で一律に $0,5,10$, 20(分)の 4 パターンの初期值を設定した.その結 果,いずれの初期值の場合も 1 回の $\xi$ の更新で, 6 分前後の值になり,3 回程度の更新でおおよそ収 束しているといえる.したがって,本ネットワーク に限られた結果ではあるものの,実規模ネットワ 一クにおける実証分析において, 平均コストを用 いた高速道路転換率内生型確率的均衡モデルは 収束することが検証できたものと考える。 


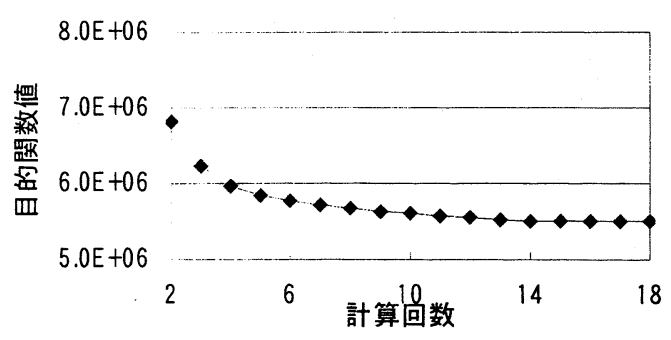

図-1 目的関数の収束状況

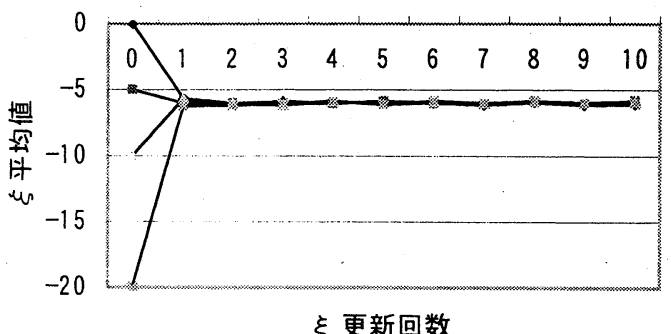

図-2 $\xi$ の収束状況

\section{2 ）分散パラメータによる精度比較}

高速道路経路と一般道経路の分散パラメータ のペアをいくつか変えて行った配分結果を表-4 に示す．高速道路と一般道の RMSE の和でみる と,高速道路パラメータ $90(1 / \mathrm{hr})$ ，一般道パラメ 一夕 10（1/hr）とする場合が最も低い值を示し ている．そのときの散布図は図-3 のようになり， 高速道路でやや過少ぎみではあるがほぼ 45 度の 直線状に載っており，比較的良好な精度といえる。 このことから,高速道路利用経路の選択は確定的 に近いものであるが,一般道利用経路の選択は高 速道路利用経路に比べ確率的に扱った方がよい という結果になった. 高速道路が確定的になる理 由は, 高速道路ネットワークの方が一般道よりも 経路選択の幅が少なく，渋滞の影響が少ないため 経路が確定されやすいことがいえると考えられ る.特に名古屋圈高速道路ネットワークは, 選択す べき経路が少ないことがあるためと思われる.逆 に,確定選択を行っている高速道路の分散を敢え て小さくすると,誤差が大きくなることもわかる.

ところで,桑原 17)は実際ネットワークにおいて, 高速道路と一般道で同じ分散パラメータを使っ た需要固定型確率的均衡配分により,分散パラメ 一夕と配分精度との興味深い関係を分析してい る.それによれば, 分散パラメータは $6(1 / \mathrm{hr})$ か
ら 60（1/hr）まで精度がよく,その間は変わらな かったとしている.本研究でもパラメータの範囲 はほぼ同様となったが,高速道路と一般道を明確 に分離することにより,各分散パラメータの影響 がより明らかとなったものと考える.

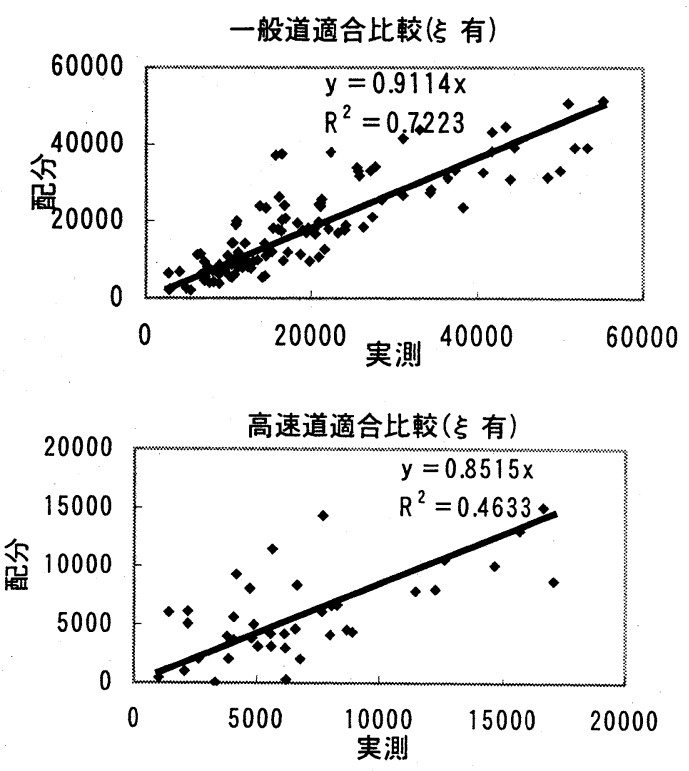

図-3 確率的均衡配分の結果

(高速道路パラメータ 90,一般道パラメータ 10)

表-4 RMS誤差による適合度比較

\begin{tabular}{|c|c|c|c|c|}
\hline $\begin{array}{l}\text { 高速道 } \\
\text { パラメ-タ }\end{array}$ & $\begin{array}{l}\text { 一般道 } \\
\text { パラx-夕 }\end{array}$ & $\begin{array}{l}\text { 高速道 } \\
\text { RMS 誤差 }\end{array}$ & $\begin{array}{c}\text { 一般道 } \\
\text { RMS 誤差 }\end{array}$ & 合計 \\
\hline 10 & 10 & 3659.7 & 6754.2 & 10413.9 \\
\hline 10 & 30 & 3893.8 & 6764.1 & 10657.9 \\
\hline 10 & 60 & 3944.1 & 6641 & 10585.1 \\
\hline 30 & 10 & 3717.8 & 6632.9 & 10350.7 \\
\hline 30 & 30 & 3712.3 & 6588.4 & 10300.7 \\
\hline 30 & 60 & 3786.3 & 6656.9 & 10443.2 \\
\hline 60 & 10 & 3593 & 6674.1 & 10267.1 \\
\hline 60 & 30 & 3678.7 & 6859.6 & 10538.3 \\
\hline 60 & 60 & 3781.3 & 6657.1 & 10438.4 \\
\hline 90 & 10 & 3653.3 & 6569.6 & 10222.9 \\
\hline 90 & 30 & 3704.9 & 6596.6 & 10301.5 \\
\hline 120 & 10 & 3699.4 & 6618.8 & 10318.2 \\
\hline 120 & 30 & 3682.5 & 6740.5 & 10423 \\
\hline$\infty$ & $\infty$ & 3747.6 & 6602.2 & 10349.8 \\
\hline
\end{tabular}

\section{3 ）確定的配分との精度比較}

表-4 で高速道路と一般道の分散パラメータを のとした配分結果は,確定的な均衡配分をした結 果と同等である.このとき,最短経路コストは利用 される経路の平均コスト及び期待最小コストと 同一である.この確定均衡の配分結果より,確定的 
に配分をおこなった場合でも十分な現況再現性 を有しているとはいえ,表-4 で示すとおり,確率的 に配分をおこなった方が,さらによい現況再現性 を有することが示された。

\section{3 期待最小コストによるモデルの配分結果} と考察

本研究で $\xi$ を導入して,平均コストの確率的均衡 を行った妥当性を考える.そのため $\xi=0$ として, 補助問題を最適化することを一度のみ行い,期待 最小コストを用いる高速道路転換率内生型確率 的均衡配分モデルの精度を考察する. 表-5 は,高 速道路の分散パラメータを 90 で固定し,一般道の 分散パラメータを変化させて, 高速道路利用 $\mathrm{OD}$ 交通量の配分結果と実測 OD 交通量との比を示 したものであるが,一般道分散パラメータが低く なるにつれて,配分 OD 交通量は過少に推定され る結果となった。

この原因は, 3.2 節で考察した期待最小コストと 平均コス卜の基本的特性にあると考えられる.前 節で精度が最もよかった分散パラメータ（高速道 路：９０，一般道：10）について,3.2 節表-2 の 結果を当てはめてみる.分散パラメータが 90 の時 の期待最小コストと平均コストのコスト差は一 0.46 であるのに対して,10 の時のコスト差は一 13.17 となる.これは（高速道路：90,一般道： 10 )のケースでは, 高速道路は期待最小コストと 平均コストはほぼ同值だが,一般道は期待最小コ ストが平均コストより大きく下回る值になるこ とを示唆するものである.よって高速道路転換率 モデルの計算に期待最小コストを用いると,特に 一般道の経路コストが実際の平均コストに比べ 小さい值をとることから,表-5 では高速道路利用

表-5 期待最小コストによる高速転換率内生型 確率的均衡配分結果

\begin{tabular}{|c|c|c|c|c|}
\hline $\begin{array}{c}\text { 高速道 } \\
\text { パラメータ }\end{array}$ & $\begin{array}{c}\text { 一般道 } \\
\text { パラメータ }\end{array}$ & $\begin{array}{c}\text { 高速道 } \\
\text { 配分/実測 }\end{array}$ & $\begin{array}{c}\text { 高速道 } \\
\mathrm{RMS} \text { 誤差 }\end{array}$ & $\begin{array}{c}\text { 全体 } \\
\mathrm{RMS} \text { 誤差 }\end{array}$ \\
\hline 90 & 1 & 0.279 & 6515.8 & 13487.2 \\
\hline 90 & 5 & 0.477 & 5347.5 & 12019 \\
\hline 90 & 10 & 0.693 & 4282.3 & 10843.7 \\
\hline 90 & 15 & 0.816 & 3881.8 & 10529.5 \\
\hline 90 & 20 & 0.874 & 3736.6 & 10326.9 \\
\hline 90 & 50 & 0.978 & 3713.8 & 10343.2 \\
\hline 90 & 60 & 0.993 & 3737.7 & 10293.3 \\
\hline
\end{tabular}

ODが過少に推定されてしまったものと考えら れる.これらの結果から本研究で開発した平均コ ストを用いた高速道路転換率内生型確率的均衡 配分モデルの有用性がわかったといえる.

\section{6. おわりに}

本研究で得られた結論及び今後の課題は以下 のようになる.

1) 高速道路転換率を含む確率的均衡配分の定式 化をおこなった. 需要関数である高速道路転換率 は, 平均コストを変数としたロジット型関数を用 いた。

2 ) 分散パラメータの違いによる期待最小コスト と平均コストの特性を分析した結果, それらのコ スト差は, 分散パラメータが小さくなる $(20$ 以下) ほど,大きくなる傾向が強い.このことから, 現実 のデータから得られる高速道路転換率モデルに 平均コストを用いる妥当性を考察できた.

3 ) 平均コストによる高速道路転換率を内生化し た確率的均衡モデルの解法を示した.このアルゴ リズムから得られる解の収束性は証明されない が, 実証分析をとおして収束することが検証でき た.

4) Simplicial Decomposition 法を応用したモデ ルの解法を用いて,開発したモデルを名古屋圈の 大規模ネットワークへ適用した.適用計算の実現 は今までに研究事例がなく,近年のコンピュータ の大幅な性能向上に起因するところが大きい.配 分結果の適合度は, 高速道路パラメータ 90(1/hr), 一般道パラメータ $10(1 / \mathrm{hr})$ を用いた場合が最も高 い再現性を示した.このことから,高速道路利用の 経路選択は確定的に近いものであり,一般道利用 の経路選択は高速道路利用経路に比べ確率的に 扱ったほうがよいことが分かった。

5 ) 期待最小コストによる高速道路転換率の確率 的均衡配分では一般道分散パラメー夕が低くな るにつれて, 高速道路利用 $0 \mathrm{D}$ 交通量は過小に推定 されるようになった. よって, 平均コストを用い た高速道路転換率の有用性が確認された。

さらに, 信頼性を高めるためには, 他の都市圈 でも本モデルを適用して収束性や実績再現性の 検証を行う必要がある.最後に, 本研究の適用計 
算において, 名古屋高速道路公社, 名古屋高速道 路協会，(株）日建設計より多大な協力を得ました. ここに感謝の意を表します。

\section{付 録}

【補助問題】の計算アルゴリズム

補助問題は, 期待最小コストを変数に持つ需要 関数を組み込んだ需要変動型確率的均衡配分モ デルであり, 数理最適化問題としての解法がいく つか開発されている ${ }^{7)}$. 本研究ではこの補助問題 を解いた後に平均コストを求める必要があるこ とから, 経路交通量を未知変数として解くことが できるSimplicial Decomposition 法を利用する. ただし，一般道利用経路及び高速道路利用経路の 分散パラメータ $\left(\mu, \mu_{e}\right)$ が異なるため, それらの 経路は別々に探索する必要がある. その点を含め, 計算アルゴリズムを以下に示す.

\section{Step A. 初期設定}

経路拡張回数を $\mathrm{m}=0$, 計算回数を $\mathrm{p}=0$, 初期一 般道利用経路集合を $K_{r s}^{m}$, 初期高速道路利用経路 集合を $K_{r s}^{e m}$ に設定し, $K_{r s}^{m}, K_{r s}^{e m}$ に対して, 初期実 行可能解となる経路交通量 $f_{k}^{r s(m)}, f_{k}^{r s, e(m)}$ を設定 する。

\section{Step B . 経路限定後の均衡解を求める}

Step B-0. 収束回数を $\mathrm{n}=0$ として, 初期経路 交通量パターンとそれに対応するリンク交通 量を設定

$$
\begin{aligned}
& f_{k}^{r s(n)}=f_{k}^{r s(m)}, f_{k}^{r s, e(n)}=f_{k}^{r s, e(m)} \\
& x_{a}^{(n)}=\sum_{k \in K_{r s}^{m !}, K_{r s}^{e m}} \sum_{r s}\left(\delta_{r s, k, a}^{e(n)} f_{k}^{e r s(n)}+\delta_{r s, k, a}^{(n)} f_{k}^{r s(n)}\right)
\end{aligned}
$$

Step B-1. 降下方向ベクトル

a) $x_{a}^{(n)}$ に応じたリンクコストの更新

b)一般道利用経路と高速道路利用経路を別々に 探索する最短経路探索を行い, $C_{k}^{r s(n)}, C_{k}^{r s . e(n)}$ を更 新

c) 高速道路転換率モデルを用いて, 高速道路利用 OD 交通量 $g_{r s}^{e(n)}$ '及び一般道利用 $0 \mathrm{D}$ 交通量 $g_{r s}^{(n)}$ 'を 設定し，これらをすべて負荷すall-0r-nothing 法 により $x_{a}^{(n) !}$ を求める.

d）ロジット型経路選択モデルにより経路集合
$K_{r s}^{m}, K_{r s}^{e m}$ に対して補助経路交通量 $f_{k}^{r s(n) \text {, }}$

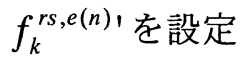

Step B-2. 一次元探索

$$
\begin{aligned}
& f_{k}^{r s(n+1)}=\alpha f_{k}^{r s(n) '}+(1-\alpha) f_{k}^{r s(n)} \\
& f_{k}^{r s, e(n+1)}=\alpha f_{k}^{r s, e(n) '}+(1-\alpha) f_{k}^{r s, e(n)} \\
& g_{r s}^{e(n+1)}=\alpha g_{r s}^{e(n)}+(1-\alpha) g_{r s}^{e(n)} \\
& g_{r s}^{(n+1)}=\alpha g_{r s}^{(n)}+(1-\alpha) g_{r s}^{(n)} \\
& x_{a}^{(n+1)}=\alpha x_{a}^{(n) '}+(1-\alpha) x_{a}^{(n)}
\end{aligned}
$$

とおき,一次元探索によって目的関数式を最小 とするステップサイズ $\alpha$ を求める

Step B-3. $\alpha$ に基づいて解を更新

Step B-4. 収束判定

収束していれば StepCへ,そうでなければ $\mathrm{n}=\mathrm{n}+1$ として Step B-1.

\section{StepC. 新たな経路の生成}

経路集合 $K_{r s}^{m}, K_{r s}^{e m}$ を拡張する。このとき,一般 道利用経路, 高速道路利用経路の最短経路探索は 文献 9）と同様である.ここでもし, 新たな経路が 見つからなければ, 4 章: 計算手順の Step1へ. そうでなければ, 経路集合を拡張し，

$$
\begin{aligned}
& f_{k}^{r s(m+1)}=f_{k}^{r s(n)}, f_{k}^{r s, e(m+1)}=f_{k}^{r s, e(n)}, \mathrm{m}=\mathrm{m}+1 \text { と } \\
& \text { して Step B-0. へ }
\end{aligned}
$$

\section{参考文献}

1) Daganz 0, C.F. and Sheffi,Y. : " On Stochastic Models of traffic Assignment, Trans.Sci. 11 (3) , pp. 253-274, 1977

2）長澤秀春・松井寛・藤田素弘 : 大都市圏道路ネ ットワークにおける確率的均衡配分の適用研 究, 土木計画学研究・講演集 No22 (2), pp195-199, 1999

3)松井 寛・藤田素弘:大都市圈道路網を対象とした 拡張型利用者均衡配分モデルの開発とその実用 化, 土木計画学研究 - 論文集 No.17, pp.15-28,2000.

4)高橋勝美,毛利雄一,井上紳一:均衡配分適用に おける課題と対応, 土木計画学研究·講演集 No25 (57), 2002

5)吉田禎雄:発展的均衡配分の適用之課題車種 別時間帯均衡配分-,土木計画学研究·講演集 
№25 (58), 2002.

6)Fisk, C. S. : "Some Developments in Equil ibrium Traffic Assignment" Trans. Res.14B(3), pp. 243-255, 1980

7)宮城俊彦,小川俊幸 : 共役性概念に基づきロジッ トモデルのパラメータ推定法,土木計画学研 究・論文集,No.3,pp 185-192,1986.

8)溝上章志,松井寛 : Fisk 型確率的均衡配分モデ ルの未知パラメータ $\theta$ の推定に関する一手法, 交通工学,No.28,pp21-29,1992.

9）赤松隆・松本嘉司：需要変動を考慮した交通 ネットワーク確率的均衡モデルとその解法,土 木学会論文集,No.401,pp109-118

10）土木計画学研究「交通ネットワーク」出版小 委員会 : 交通ネットワークの均衡分析 一最新 の理論と解法 一, 土木学会, 1998.

11) HAI YANG : MULTIPLE EQUILIBRIUM BEH AVIORS AND ADVANCED TRAVELER INFORMATION SYSTEMS WITH ENDOGENOUS MARKETPENETRATION, Transp Res-B , Vol. 32, No. 3, pp205-218, 1998

12）松井 寛・藤田素弘:高速道路を含む都市圈道 路網における利用者均衡配分モデルの実用化に 関する研究,土木学会論文集 No.653/IN-48, pp.85-94,2000.

13)名古屋高速道路公社 : 第 7 回名古屋高速道 路自動車起終点調査, 1996.

14）中京都市圈総合都市交通計画協義会: 第3回中 京都市圏パーソントリップ調査報告書, 1993 .

15）名古屋高速道路公社・名古屋高速道路協会： 名古屋高速道路の交通量配分手法に関する実 証的調查研究委員会報告書, 1997 .

16)建設省道路局編・(社) 交通工学研究会: 平 成6年度道路交通センサス, 1995 .

17)桑原雅夫：“交通量配分手法の実証的検討”， 交通工学,vol.23,No.2,pp.17-25,1988 